\title{
Three new graminicolous species of Curvularia (anamorphic fungi) from Queensland, Australia
}

\author{
Asaipillai Sivanesan $^{\mathrm{A}}$, John L. Alcorn ${ }^{\mathrm{A}}$ and Roger G. Shivas ${ }^{\mathrm{A}, \mathrm{B}}$ \\ ${ }^{A}$ Department of Primary Industries, Plant Pathology Herbarium, 80 Meiers Road, Indooroopilly, Qld 4068, \\ Australia. \\ ${ }^{\mathrm{B} C}$ Corresponding author; roger.shivas@dpi.qld.gov.au
}

\begin{abstract}
Three new species of Curvularia, C. bothriochloae sp. nov., C. micrairae sp. nov. and C. queenslandica sp. nov., isolated from grass hosts in Queensland are described, illustrated and compared with closely related species.
\end{abstract}

\section{Introduction}

About 38 graminicolous Curvularia species have been described (Sivanesan 1987; Morgan-Jones 1988; Boerema and Hamers 1989; Alcorn 1990, 1991, 1998). Eleven species among them are known to have conidia with a distinctly protuberant hilum (Sivanesan 1987). In this paper, one species with a distinctly protuberant hilum, another species with a slightly protuberant hilum and a third species with an inserted hilum could not be matched in conidial morphology, size and septation with any of the known species of Curvularia. Three new graminicolous species are described, illustrated and compared with species of similar conidial morphology.

\section{Methods}

Observations and measurements were made of fungal structures taken from dried cultures and mounted in lactophenol. Photomicrographs were taken with a digital camera (Leica DC 200 with IM 1000 Multifocus Module). Living cultures are deposited in the Plant Pathology Herbarium (BRIP), Queensland Department of Primary Industries.

\section{Media and fungal growth conditions}

Tap water agar (TWA) + wheat straw was used as a growth medium. Mature conidia were formed between 7 and 10 days when plates were exposed to a near-ultraviolet light source on $12 \mathrm{~h}$ diurnal cycle at room temperatures of $20-30^{\circ} \mathrm{C}$.

\section{Taxonomy}

Curvularia bothriochloae Sivan., Alcorn \& R.G.Shivas, sp. nov. (Fig. 1a,b)

Etymology: based on Bothriochloa, the name of the host genus.

Teleomorph: unknown.
Coloniae in agaro 'TWA + wheat straw' brunneae vel atrobrunneae, floccosae. Hyphae pallide brunneae, ramosae, septatae, laeves, usque ad $7.5 \mu \mathrm{m}$ crassae. Conidiophora singularia, gregaria, simplicia, recta vel curvata, supra geniculata, septata, pallide brunnea vel brunnea, versus apicem pallidiora, variabilia amplitudine, 360-425 $\times$ 3-6 $\mu \mathrm{m}$. Cellulae conidiogenae polyblasticae, sympodiales, in conidiophoris incorporatae, terminales, interdum intercalares, cicatricatae. Conidia acropleurogena, 3-septata, recta vel curvata, ad cellulam tertiam ab infimo paulo latiorem, maiorem, cellulis extimis subhyalinis vel pallide brunneis, cellulis intermedii pallide brunneis vel atrobrunneis, $30-47 \times 15-25 \mu \mathrm{m}$, hilo distincte protrudente ex cellula basilari, germinatio bipolaris.

Holotypus: Australia, Queensland, Goondiwindi, on leaves of Bothriochloa bladhii (Retz.) S.T.Blake, J.L. Alcorn 77135, 12.v.1977, BRIP12522.

Colonies in TWA + wheat straw brown to dark brown, floccose. Hyphae pale brown, branched, septate, smooth, up to $7.5 \mu \mathrm{m}$ thick. Conidiophores single or grouped, unbranched, straight to flexuous, geniculate above, septate, pale brown to brown, apex paler, variable in length, 360-425 $\times$ 3-6 $\mu \mathrm{m}$. Conidiogenous cells polyblastic, sympodial, terminal, sometimes intercalary, cicatrized. Conidia acropleurogenous, 3-septate, straight to curved at the slightly wider, larger third cell from the base, end cells subhyaline to pale brown, intermediate cells pale brown to dark brown, $30-47 \times 15-25 \mu \mathrm{m}$, hilum distinctly protuberant from the basal cell. Germination of conidia is bipolar.

Other specimen examined: Australia, Q1d, Yelarbon: isolated from leaves of Dichanthium sericeum (R.Br.) A.Camus, J. L. Alcorn 77125b, 11.v.1977, BRIP 12512 . 

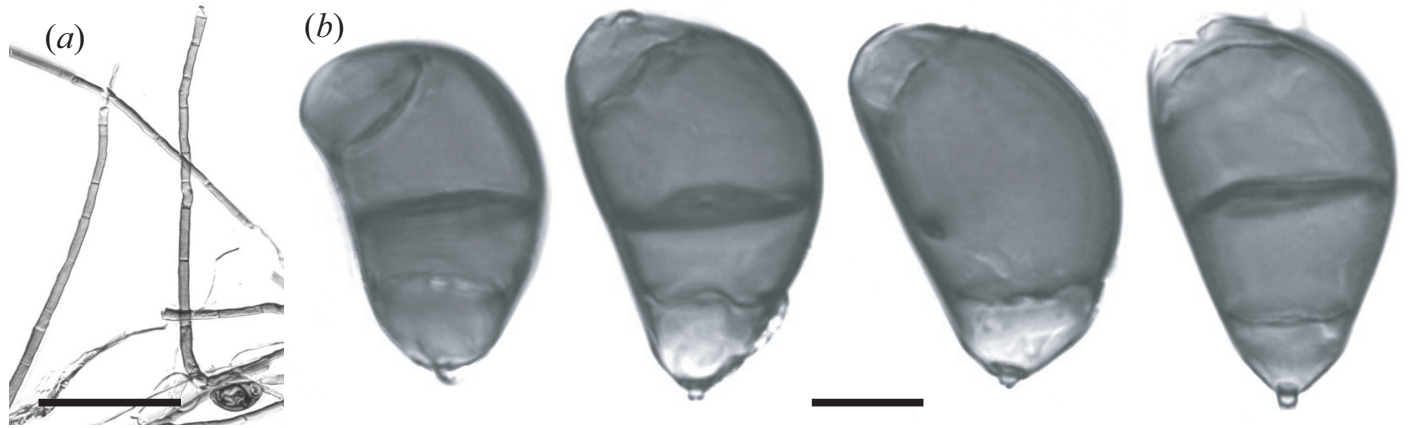

Fig. 1. Curvularia bothriochloae (holotype). (a) Conidiophores, scale bar $=100 \mu \mathrm{m}$. (b) Conidia, scale bar $=10 \mu \mathrm{m}$.

Table 1. Comparison of conidial sizes in closely related Curvularia species

\begin{tabular}{ll}
\hline Species & Conidial size $(\mu \mathrm{m})$ \\
\hline C. akaii & $24-34 \times 8-14$ \\
C. akaiiensis & $22.5-27.5 \times 7.5-15.5$ \\
C. bothriochloae & $30-47 \times 15-25$ \\
C. gudauskasii & $27-29 \times 15-19$ \\
\hline
\end{tabular}

\section{Notes}

This species has conidia similar in shape and septation to those of C. akaii Tsuda \& Ueyama (1985), C. akaiiensis Sivan. (1987) and C. gudauskasii Morgan-Jones \& G.W.Karr (1976) but the conidia are significantly longer and wider than in these three species. Comparison of conidial measurements is given in Table 1. C. akaii and C. akaiiensis are also known to have a Cochliobolus teleomorph (Sivanesan 1987). C. bothriochloae is presumably heterothallic as no teleomorph was formed in single-spore cultures. Other Curvularia species reported on Bothriochloa and Dichanthium, respectively, are C. andropogonis (Zimm.) Boedijn and C. robusta Kilp. \& Luttr. (Sivanesan 1987) and both these species have larger conidia than $C$. bothriochloae. C. bothriochloae is associated with leaf and leaf-sheath spotting on its hosts.
Curvularia micrairae Sivan., Alcorn \& R.G.Shivas, sp. nov. (Fig. 2a, $b$ )

Etymology: based on Micraira, the name of the host genus.

Teleomorph: unknown.

Coloniae in agaro 'TWA + wheat straw' brunneae, floccosae. Hyphae pallide brunneae, ramosae, septatae, laeves, 4-7.5 $\mu \mathrm{m}$ crassae. Conidiophora singularia vel gregaria, interdum orientia a stromate parvo immerso, simplicia, recta vel curvata, supra geniculata, septata, pallide brunnea, variabilia longitudine, 220-500 × 9-15 $\mu \mathrm{m}$. Cellulae conidiogenae polyblasticae, sympodiales, in conidiophoris incorporatae, terminales, interdum intercalares, cicatricatae. Conidia acropleurogena, recta, clavata, 3-septata, pallide brunnea, laevia praeter cellulam basalum quae est verruculosa, cellula tertia ab infimo paulo longior et latior quam cellulae ceterae, cellula apicalis apice complanata, concoloria, 34-38 × 13-17 $\mu \mathrm{m}$. Stromata in cultura formata, atra, fere, cylindrica sed latitudine aliquantum irregularia, simplicia vel ramosa, usque ad $3200 \mu \mathrm{m}$ alta $\times 380 \mu \mathrm{m}$, conidiophora et setas ferentia.

Holotypus: Australia, Queensland, Mount Ngungun National Park, on leaves of Micraira subulifolia F.Muell., J.L. Alcorn 9071, 19.v.1990, BRIP 17068a.

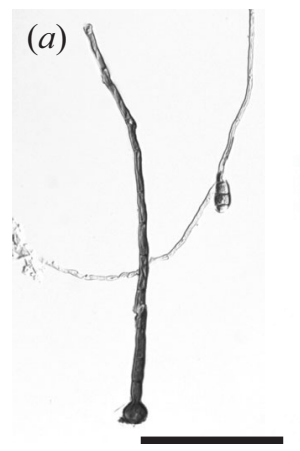

(b)

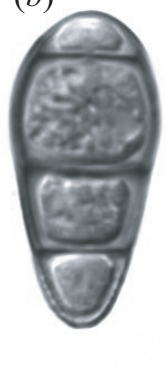

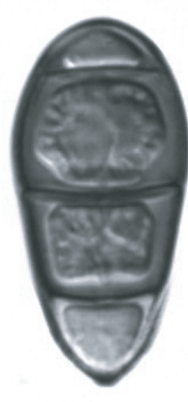
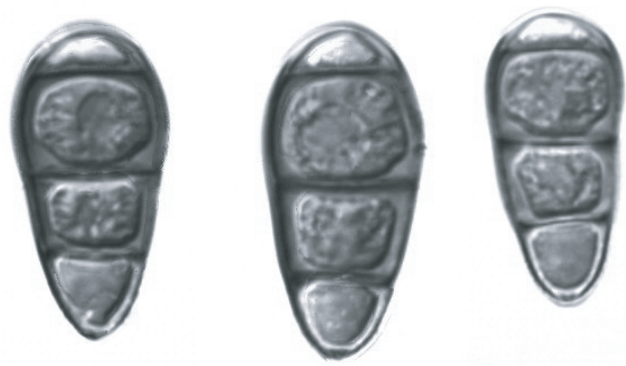

Fig. 2. Curvularia micrairae (holotype). (a) Conidiophore, scale bar $=100 \mu \mathrm{m}$. (b) Conidia, scale bar $=10 \mu \mathrm{m}$. 
Colonies in TWA + wheat straw brown, floccose. Hyphae pale brown, branched, septate, smooth, 4-7.5 $\mu \mathrm{m}$ thick. Conidiophores single or in small groups, sometimes arising from a small immersed stroma, unbranched, straight to flexuous, geniculate above, pale brown, septate, variable in length, $220-500 \times 9-15 \mu \mathrm{m}$. Conidiogenous cells polyblastic, sympodial, incorporated in the condiophores, terminal, sometimes intercalary, cicatrized. Conidia acropleurogenous, 3-septate, straight, clavate, pale brown, concolorous, smooth except for the basal cell which is verruculose, $34-38 \times 13-17 \mu \mathrm{m}$, third cell from the base slightly longer and wider than the other cells, apical cell with a flattened apex. Stromata formed in culture, black, more or less cylindrical, somewhat irregular in width, simple or branched, up to $3200 \mu \mathrm{m}$ high $\times 380 \mu \mathrm{m}$ wide, bearing conidiophores and setae.

\section{Notes}

This species resembles C. clavata Jain (Sivanesan 1987) in its clavate, 3-septate conidia but the conidia of $C$. micrairae are significantly larger than those of $C$. clavata that measure 17-29 $\times 7-13 \mu \mathrm{m}$. No species of Curvularia has been reported on Micraira. $C$. micrairae was associated with leaf tip dieback and leaf spot of Micraira. The species is presumably heterothallic as no teleomorph was formed in single-spore cultures.

Curvularia queenslandica Sivan., Alcorn \& R.G.Shivas, sp. nov. (Fig. $3 a-c$ )

Etymology: based on place of collection.

Teleomorph: unknown.

Coloniae in agaro 'TWA + wheat straw' brunneae vel atrobrunneae, floccosae. Hyphae pallide brunneae, ramosae, septatae, laeves, 2-4.5 $\mu \mathrm{m}$ crassae. Conidiophora singularia, simplicia, recta, supra geniculata, septata, brunnea vel atrobrunnea, concoloria, 94-200 × 7.5-9.5 $\mu \mathrm{m}$. Cellulae conidiogenae polyblasticae, sympodiales, in conidiophoris incorporatae, terminales, interdum intercalares, cicatricatae. Conidia cylindrica vel cylindrico-fusiformia, acropleurogena, 4-6-septata, plerumque 5-septata, recta vel plerumque curvata ad plerumque cellulam tertiam ab infimo longiorem et latiorem, fortasse haec cellula postea septum secundum pariet, aliae cellulae aequalis vel fere dense septatae, cellulis minoribus extremis atrobrunnea, concoloria, $50-78 \times 11.5-21 \mu \mathrm{m}$. Stromata in cultura formata. Germinatio bipolaris.

Holotypus: Australia, Queensland, Severnlea, on leaves of Eragrostis brownii (Kunth) Nees ex Steud., J.L. Alcorn 7737c, 28.ii.1977, BRIP 12100.

Colonies in TWA + wheat straw brown to dark brown, floccose. Hyphae pale brown, branched, septate, smooth, 2-4.5 $\mu \mathrm{m}$ thick. Conidiophores single, unbranched, straight, geniculate above, septate, brown to dark brown, concolorous, 94-200 × 7.5-9.5 $\mu \mathrm{m}$. Conidogenous cells polyblastic, sympodial, incorporated in conidiophores, terminal, sometimes intercalary, cicatrized. Conidia cylindrical to cylindric-fusiform, acropleurogenous, 4-6-septate, predominantly 5-septate, straight to mostly curved at the usually longer and wider third cell from the base and this cell may develop an additional septum later, other cells equal or fairly closely septate with smaller end cells, dark brown, concolorous, $50-78 \times 11.5-21 \mu \mathrm{m}$, with a slightly protruding hilum. Stromata formed in culture. Germination of conidia is bipolar.
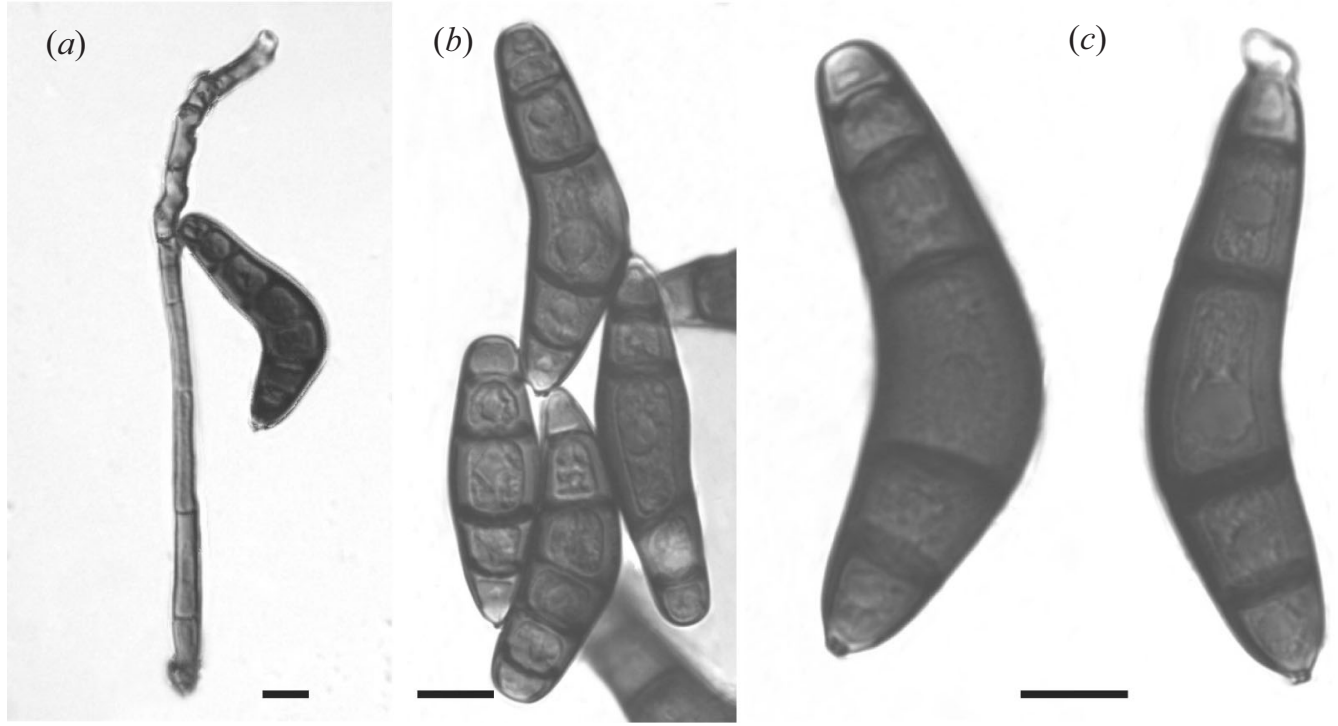

Fig. 3. Curvularia queenslandica (holotype). (a) Conidiophore and conidium, scale bar $=10 \mu \mathrm{m} .(b, c)$ Conidia, scale bar $=10 \mu \mathrm{m}$. 
Notes

In the number of septa in the conidia, this species is close to C. inaequalis (Shear) Boedijn and C. oryzae-sativae Sivan. (Sivanesan 1987). The conidia of $C$. inaequalis are 2-6-septate, predominantly 4-septate and measure 24-45 $\times$ 9-16 $\mu \mathrm{m}$ and in C. oryzae-sativae they are 3-8 (mostly $6-7$ )-septate and measure $22-40 \times 9-11.5 \mu \mathrm{m}$. The hilum is not protuberant in $C$. inaequalis and is only slightly protuberant in C. oryzae-sativae. C. queenslandica is easily separable from these two species by its significantly longer and wider conidia. C. eragrostidis (Henn.) J.A.Meyer and C. lunata (Wakker) Boedijn are two other Curvularia species reported on Eragrostis. C. queenslandica is associated with leaf spots. This species is presumably heterothallic as no teleomorph was formed in single-spore cultures.

\section{References}

Alcorn JL (1990) Additions to Bipolaris, Cochliobolus and Curvularia. Mycotaxon 39, 361-392.

Alcorn JL (1991) New combinations and synonymy in Bipolaris and Curvularia, and a new species of Exserohilum. Mycotaxon 41, 329-343.
Alcorn JL (1998) A new Cochliobolus species and its Curvularia anamorph. Proceedings of the Royal Society of Queensland 107, $1-4$.

Boerema GH, Hamers MEC (1989) Check-list for scientific names of common parasitic fungi. Series 3b: fungi on bulbs: Amaryllidaceae and Iridaceae. Netherlands Journal of Plant Pathology 95 (Supplement 3), 1-32.

Morgan-Jones G (1988) Notes on hyphomycetes LXI. Curvularia bannonii sp. nov., an undescribed leaf pathogen of Jacquemontia tamnifolia. Mycotaxon 33, 407-412.

Morgan-Jones G, Karr Jr GW (1976) Notes on hyphomycetes. IX. A new species of Curvularia. Mycotaxon 3, 559-563.

Sivanesan A (1987) Graminicolous species of Bipolaris, Curvularia, Drechslera, Exserohilum and their teleomorphs. Mycological Papers 158, 1-261.

Tsuda M, Ueyama A (1985) Two new Pseudocochliobolus and a new species of Curvularia. Transactions of the Mycological Society of Japan 26, 321-330.

Manuscript received 2 April 2002, accepted 23 October 2002 